\title{
İktisadi Sosyolojiden Yeni İktisat Sosyolojisine: İktisat ve Sosyoloji iliş̧kisinin Değişen Yüzü
}

Gülenay BAŞ DİNAR, Department of Economics, Faculty of Economics and Administrative Sciences, Abant Izzet Baysal University, Turkey; e-mail: gulenaybas@ibu.edu.tr

\section{From the Economic Sociology to the New Economic Sociology: The Changing Face of the Relation between Economics and Sociology}

\begin{abstract}
This study aims to put forth the diversities between the economic sociology that was founded at the beginning of the last century and the New Economic Sociology that was established at the middle of 80 s and is popular nowadays especially in the USA. The new economic sociology has changed the traditional relation between the economics and sociology. While the economic sociology approach that emerged at the beginning of last century has worked on a ground that may be resumed as an evaluation of the economic events from a sociological standpoint; the new economic sociology approach that emerged at 80s has the opposite content that evaluates the sociological events with an economic view point. It may be said that due to that quality, the new economic sociology approach is a typical example for the methological imperialism of the economics. This study consists of three parts. In the first part, the transformation of the relation between economics and sociology will be examined; secondly the main principles of the economic sociology based on the ideas of Weber and Durkheim will be assessed and lastly, along with a critical examination of the new economic sociology, the study will end with an evaluation of what may be done in order to reattach the bonds between the economics and the society that were already cut off.
\end{abstract}

Keywords

Economic Sociology, New Economic Sociology, Weber, Durkheim, Methodological Individualism.

JEL Classification Codes : $\quad$ B41, B50, Z13.

Öz

Bu çalışma 20. Yüzyılın başında ortaya çıkan iktisadi sosyoloji yaklaşımının 1980'li yıllarda ortaya çıkan ve günümüzde özellikle Amerika'da etkili olan yeni iktisat sosyolojisi ile farklılıklarını ortaya koymayı amaçlamaktadır. Yeni iktisat sosyolojisi yaklaşımı iktisat ve sosyoloji arasındaki geleneksel ilişkinin biçim değiştirmesine neden olmuştur. 20. Yüzyılın başında ortaya çıkan iktisadi sosyoloji yaklaşımı iktisadi olayları sosyolojik bir bakış açısı ile değerlendirmek biçiminde özetlenebilecek bir temel üzerinden hareket etmekteyken; 1980'lerde ortaya çıkan yeni iktisat sosyolojisi yaklaşımı sosyolojik olayları iktisadi bir bakış açısı ile değerlendirmek gibi tam tersi bir içeriğe sahiptir. Bu özelliği nedeniyle, yeni iktisat sosyolojisi yaklaşımı iktisadın mantığının ve yönteminin diğer sosyal bilimlere uygulanması anlamında iktisadın metodolojik emperyalizminin tipik 
bir örneğini oluşturmaktadır. Bu çalışma üç bölümden oluşmaktadır. Birinci bölümde, iktisat ve sosyoloji arasındaki ilişkinin geçirdiği değişim incelenecek; ikinci olarak Weber ve Durkheim'ın görüşlerine dayanarak iktisadi sosyoloji yaklaşımının temel esasları değerlendirilecek; çalışma yeni iktisat sosyolojisi yaklaşımının eleştirel bir incelemesiyle günümüzde iktisat ve toplum arasında kopan bağları tekrar birleştirmek için yapılması gerekenlerin değerlendirilmesi ile son bulacaktır.

Anahtar Sözcükler : İktisat Sosyolojisi, Yeni İktisat Sosyolojisi, Weber, Durkheim, Yöntemsel Bireycilik.

\section{Giriş}

İktisat ve sosyoloji bilimleri arasındaki ayrışmanın kökenleri 19. yüzyıla aittir. İktisadın diğer sosyal bilimlerden bağımsız bir bilim olarak kendisini ortayla koyması ile birlikte ekonomi ve toplum birbirlerinden bağımsız alanlar gibi incelenmeye başlanmış; iktisat ekonominin alanına giren konularla sosyoloji de toplumsal alana ilişkin konularla ilgilenmiştir. 20. yüzyılın başında Weber ve Durkheim gibi düşünürler iktisadi sosyoloji yaklaşımını geliştirmişler ve iktisadi olayların toplumsal alandan yalıtılarak incelenemeyeceğini ileri sürerek iktisadi olayların analizine sosyolojik bir bakış açısı önermişlerdir. 20. Yüzyılın başında Almanya'da tarihçi okul, ABD'de kurumsal iktisat okulu gibi okullar böyle bir yaklaşımın gerekliliğini ısrarla vurgulamışlardır. 1930'lardan sonra neoklasiklerin tümden gelim yönteminin iktisada hâkim olmasıyla birlikte neoklasik modeller iktisada hâkim olmuş; 1930'lardan 1970'lere kadar soyut ekonomik modeller ortaya konularak iktisadın tarih ve sosyoloji ile olan bağı ciddi bir şekilde zayıflatılmıştır.

1970’lerden itibaren yeni kurumsal iktisat okulunun kurumları neoklasik iktisada dahil etme çabası ile birlikte iktisadın sınırları genişletilmeye çalışılsa da, yeni kurumsal iktisat kurumları son derece dar ve indirgemeci bir bağlamda ele alması nedeniyle iktisadın tarih ve toplum ile bağlarının güçlenmesini sağlama konusunda bir katkıda bulunamamıştır. 1980'lerde doğan yeni iktisat sosyolojisi yeni kurumsal iktisatçıları eleştirmek ve iktisat ve sosyoloji arasında yakın işbirliğini önermekle birlikte yeni iktisat sosyolojisi zamanla iktisadın indirgemeci mantığının sosyolojiye uygulanması biçimine dönüşmüş ve Ben Fine'ın “iktisat emperyalizmi” olarak tanımladığı sürece katkıda bulunmuştur.

$\mathrm{Bu}$ çalışma 20. yüzyılın başında ortaya çıkan iktisadi sosyoloji yaklaşımının 1980’li yıllarda ortaya çıkan ve günümüzde özellikle Amerika'da etkili olan yeni iktisat sosyolojisi ile farklılıklarını ortaya koymayı amaçlamaktadır. Yeni iktisat sosyolojisi yaklaşımı iktisat ve sosyoloji arasındaki geleneksel ilişkinin biçim değiştirmesine neden olmuştur. 20. Yüzyılın başında ortaya çıkan iktisadi sosyoloji yaklaşımı iktisadi olayları sosyolojik bir bakış açısı ile değerlendirmek biçiminde özetlenebilecek bir temel üzerinden hareket etmekteyken; 1980'lerde ortaya çıkan yeni iktisat sosyolojisi yaklaşımı sosyolojik olayları iktisadi bir bakış açısı ile değerlendirmek gibi tam tersi bir içeriğe sahiptir. Bu 
özelliği nedeniyle, yeni iktisat sosyolojisi yaklaşımı iktisadın mantığının ve yönteminin diğer sosyal bilimlere uygulanması anlamında iktisadın metodolojik emperyalizminin tipik bir örneğini oluşturmaktadır. Bu çalışma üç bölümden oluşmaktadır. Birinci bölümde, iktisat ve sosyoloji arasındaki ilişkinin geçirdiği değişim incelenecek; ikinci olarak Weber ve Durkheim'ın görüşlerine dayanarak iktisadi sosyoloji yaklaşımının temel esasları değerlendirilecek; çalışma yeni iktisat sosyolojisi yaklaşımının eleştirel bir incelemesiyle günümüzde iktisat ve toplum arasında kopan bağları tekrar birleştirmek için yapılması gerekenlerin değerlendirilmesi ile son bulacaktır.

\section{2. İktisat ve Sosyoloji Arasındaki İlişskinin Geçmişine Bir Bakış}

İktisat ve sosyoloji arasındaki ilişki ile ilgili tartışmaların kökeni çok eskiye gitmektedir. Antik Yunan filozofları toplumu bir bütün olarak düşünmüşler ve toplumun mutluluğunu sağlayacak ideal toplumsal örgütlenme modelinin ne olduğu üzerinde kafa yormuşlardır. Antik yunan filozoflarının gözünde ekonomi toplumsal hayatın yalnızca bir bölümünü oluşturur. Bu nedenle, bu düşünürler esas olarak politik olanla ilgilenmişler ve politikayı bilimlerin yücesi olarak tanımlamışlardır. İdeal toplumsal örgütlenme modelinin ne olduğunu tartışırken paradan, mülkiyetten ve ticaretten bahsederek iktisadın kapsamına giren konuları da gündemlerine almışlardır. Bu nedenle, antik çağ filozofları politik yaşamın yanı sıra iktisadi yaşama ilişkin öğretiler de geliştirmişlerdir (Denis, 1997: 13).

13. ve 14. yy'dan itibaren Batı Avrupa'da ticaretin canlanması ile birlikte zenginliğin ve sermaye birikiminin artırılması toplumun öncelikli amacı haline gelmiş ve buna paralel bir şekilde vurgu toplumsal alandan çok ekonomik olana yapılmıştır. Bu durum politikadan ve toplumsal yaşamdan ayrı bağımsız bir iktisat disiplinin ortaya çıkmasına zemin hazırlamıştır.

Fizyokrat Okul'un önemli temsilcilerinden Quesnay geliştirdiği makro-ekonomik modelle ekonomiyi bir bütün olarak analiz etmiş ve iktisadi model oluşturma girişiminin öncülüğünü yapmıştır. A. Smith Quesnay’dan etkilenmiş iktisadi yaşama ilişkin bir takım teoriler ortaya koymuştur. Ancak, Smith iktisadi alan ve siyasi alan arasında herhangi bir ayrım yapmamıştır. Bu nedenle, Smith'in zamanında politik ve toplumsal alandan ayrı bağımsız bir iktisat disiplinin olduğunu söylemek güçtür. Ricardo soyut bir ekonomik model ortaya koymuş ve ürettiği teorilerin zamandan ve mekandan bağımsız evrensel olduğunu ileri sürmüştür. Ricardo'nun teorisi soyut bir teori olmakla birlikte politik niteliğini sürdürmeye devam etmiştir. Ricardo Ekonomi Politiğin ve Vergilendirmenin İlkeleri kitabının giriş bölümünde analizini ekonomi politik ifadesi ile tanımlamış ve ekonomi politiğin amacını da toplam üretimin toplumun sınıfları arasındaki bölüşümünü düzenleyen yasaların belirlenmesi olarak ifade etmiştir (Ricardo, 1997: 23). Bu çerçevede, Ricardo 
toplumsal sınıflara ve toplumsal sınıflar arasındaki bölüşüm ilişkilerine analizinde merkezi bir önem vermiştir.

Ricardo'nun soyut analizine rağmen klasik ekonomi politiğin temel amac1 kapitalist ekonominin işleyişini anlamak olmuştur. Bunun için tarihsel ve toplumsal faktörlere analizlerinde yoğun bir şekilde yer vermişlerdir. Bu anlamda, Adam Smith'den, John Stuart Mill'e ve Karl Marx'a kadar her biri ekonomiyi toplumsal ve tarihsel ortamin bir parçası olarak görmüşler ve ekonomi politik terimini birleştirilmiş bir sosyal bilim anlamında kullanmışlardır (Fine \& Milakonis, 2014: 21).

19. Yüzyılın ilk yarısında Almanya'da ortaya çıkan Alman tarihçi okulu klasik iktisatçıların ortaya koyduğu teorileri zaman ve mekândan bağımsız olarak sunmasına önemli itirazlar yöneltmiştir. Bu çerçevede, Alman tarihçi okulu iktisatçıları iktisadi olayların saf ekonomik olaylar olarak görülemeyeceğini düşünmüşler ve bütüncül bir sosyal bilim anlayışı önermişlerdir. Bu şekilde tarih başta olmak üzere sosyal bilimlerin tüm alanlarından yararlanılması gerektiğini ileri sürmüşlerdir.

19. Yüzyılın sonlarına doğru ortaya çıkan marjinalist devrim iktisattaki soyutlama düzeyini muazzam bir şekilde artırmış ve iktisadın toplumdan koparılma girişimi de bu şekilde en uç noktasına vardırılmıştır. İktisat insanı ve toplumu çok mekanik bir şekilde tanımlayarak iktisadı sosyal ve siyasal alandan tamamen kopartmakla kalmamış; iktisadın alanının da iyice daralmasına neden olmuştur. Üretim ve bölüşüm alanları temel odak olmaktan çıkarılmış ve iktisadın alanı büyük ölçüde mübadele ilişkileri ile sınırlandırılmıştır. Aşırı soyut varsayımlar ve matematiğin dili kullanılarak piyasa ilişkilerine dair evrensel yasalar ortaya konulmak istenmiştir. Bu şekilde sosyal ve siyasal alandan bağımsız bir iktisat teorisi yaratılmaya niyetlenilmiştir ${ }^{1}$. Neoklasik iktisadın temellerini oluşturan Jevons, Menger ve Walras gibi iktisatçıların yaptıkları çalışmalar sonucunda iktisat üretim ve bölüşüm gibi alanlardan çok piyasadaki mübadele ilişkilerine dair deterministik açıklamalar getirmeye odaklanan bir bilim haline gelmiştir.

Marjinalist devrimin başladığı 1870’ler ile İkinci Dünya Savaşı arası dönemde iktisatta çoğulcu bir yaklaşım öneren görüşler ortaya çıkmıştır. Bu dönemde tarihçiler ve marjinalistler ekonomi politiği dönüştürme yolunda önemli çabalar sarf etmişlerdir. Bu bağlamda, tarihçiler tarihsel araştırmalara, kurumsal yapılara ve somut iktisadi süreçlerin

1 19. Yüzyılın sonunda ve 20. yüzyılın başında ABD'de ortaya çıkan kurumsal iktisat okulu Neoklasik iktisadın bu yapısına önemli eleştiriler getirmiştir. Kurumsal iktisatçılardan Veblen "İktisat Neden Evrimsel Bir Bilim Değildir?" başlıklı makalesinde Neoklasik iktisadın gerçekliği açıklamaktan uzak soyut yapısını eleştirmiş ve evrimsel bir bilim önerisinde bulunmuştur (bkz. Baş Dinar, 2011). 
analiz edilmesine vurgu yaparken, marjinalistler ise değer yargılarından bağımsız bir iktisat bilimi oluşturma çabası içinde olmuşlardır. İktisadın diğer sosyal bilimlerden, özellikle tarihten, koparılması marjinalist devrimin üç kurucusu olan William Stanley, Jevons, Leon Walras ve Carl Menger'in ortak hedefi olmuştur (Fine \& Milokanis, 2014: 22- 4).

1930’lu yıllardan itibaren marjinalist okulun giderek güçlenmesi tümdengelimci yöntemin iktisada hakim olmasına neden olmuştur. Bu süreçte toplum, bireylerin basit bir toplamı olarak görülmeye başlanmış; ekonomi de piyasa ilişkilerine indirgenerek tarihsel ve toplumsal bağlamdan koparılmıştır. Bu süreçte, toplumsal ve politik ilişkiler arka planda veri olarak kabul edilerek, toplumsal ilişkilerden soyutlanan davranışın sadece iktisadi yönleri ile ilgilenilmiştir. İktisadın tarih ve sosyoloji gibi disiplinlerle bağının tamamen koptuğu bu dönem ilginç bir şekilde diğer sosyal bilimlerin gelişmesine zemin hazırlamıştır. Bu gelişmelerle birlikte sosyal bilimler ekonomi, sosyoloji, psikoloji ve siyaset bilimi gibi alt disiplinlere ayrılmış; her bir alt disiplin kendi içindeki konularla ilgilenerek bir bütün olarak toplumsal meselelerden uzaklaşılmıştır. Sosyal bilimlerin alt dallara ayrılarak birbirlerinden ayrılması bu bilimlerin gerçek yaşamla olan ilgisinin azalmasına zemin hazırlamıştır. Bu gelişmeler kendilerine özgü yöntemlere ve dile sahip olan birbiriyle ilişkisiz pek çok sosyal bilim dalının ortaya çıkmasına neden olmuştur (Timur, 2013: 14).

Sosyoloji iktisadın bireyci yaklaşımı ve piyasa ilişkilerine odaklanan yapısı nedeniyle ilgilenmediği toplumsal alana hâkim olmuştur. Bu şekilde iktisadın terk ettiği piyasa dişı alanlar sosyolojinin inceleme alanına girmiştir (Kalleberg, 1995: 1208). 1890 ve 1930 yılları arasında Weber, Durkheim, Sombart ve Schumpeter gibi düşünürler Alman İktisat Sosyolojisi geleneğini oluşturmuşlardır. Tarihsel yaklaşımların önemini vurgulayan bu gelenek iktisadi gelişme ve ekonomide devletin rolü gibi konular üzerinde durmuştur. $\mathrm{Bu}$ yaklaşımda aynı zamanda uluslararasında çeşitli karşılaştırmalı analizler yapılarak iktisadın kültürel bir bilim olduğunun altı çizilmiştir (Swedberg, 1991: 258-9). Yine bu dönemde Amerika' da kurumsal iktisatçılar iktisadi konulara sosyolojik bir bakış açısı ile yaklaşmışlar ve iktisat teorisi oluşturulurken psikoloji, tarih, sosyoloji gibi bilim dallarından yararlanılması gerektiğini vurgulayarak bütüncül bir sosyal bilim anlayışı önermişlerdir. Bu bakış açısı ile anaakım iktisadı somut iktisadi süreçleri incelememeleri nedeniyle eleştirmişler ve evrim ve iktisadi değişme süreçlerini analiz etmeyi amaçlamışlardır. Bu açıdan analizlerinde iktisadın işlevsel bir bilim olması gerektiğini ileri sürerek pragmatik bir yaklaşımı benimsemişlerdir.

1930'lardan 1970'lere kadar olan süreçte iktisatçılar ve sosyologlar arasındaki iletişim son derece sınırlı düzeyde olmuştur. Marjinalizmin yükselmesiyle birlikte bir yandan ekonomi piyasa ilişkilerine indirgenirken, diğer yandan geliştirilen denge, rasyonalite, kıtlık ve seçim gibi temel kavramsal ilkeler evrensel ilkeler gibi sunulmuştur. Benimsenen yöntemsel bireycilik ve ekonomik indirgemecilik iktisadın tarihsel ve 
toplumsal yapıdan bağımsız bir disiplin haline dönüşmesine neden olmuştur. Ancak, ilginç bir şekilde toplumsal ilişkilerden uzak duran iktisat biliminin geliştirdiği kavramsal ve analitik çerçeve sadece iktisadi olayların analizi için değil tüm toplumun analizi için uygulanmaya başlamıştır. $\mathrm{Bu}$ süreç toplumsal ilişkilerin ve toplumsal yapıların piyasa ilişkilerinin mantığı ile açıklanmasına neden olmuştur. Bu süreçte, Becker ${ }^{2}$ gibi iktisatçılar her şeyin iktisadi rasyonaliteye indirgenebileceği düşüncesinden hareketle beşeri sermaye, aile, suç vb. konuları da iktisadın mantığı ile açıklamaya niyetlenmişlerdir (Fine \& Milokanis, 2014: 31-2).

1970'lerden itibaren iktisat ve sosyoloji arasında iletişimin giderek arttığ1 görülmektedir. Bu ilgi büyük ölçüde sosyologların çalışma alanına giren konuların iktisadın yöntemleri ve mantığı ile ele alınması biçiminde gerçekleşmiştir. 1970'lerden itibaren yeni kurumsal iktisat ve yeni iktisat sosyolojisi gibi akımların ortaya çıkmasına neden olan faktör neoklasik iktisadın kurumları açıklama başarısızlığıdır. 19. Yüzyılın sonunda marjinalizmin doğuşu ile birlikte iktisatçılar kurumsal yapı ile ilgilenmeyi bırakmışlardı. 1970'li yıllardan itibaren iktisatçılar ve sosyologlar işlem maliyetleri, mülkiyet hakları ve oyun teorisi perspektifinde kurumlarla ilgilenmeye başladılar. $\mathrm{Bu}$ anlamda, makro-sosyolojik bir perspektiften uzaklaşarak mikro-sosyolojik konularla ilgilendiler (Caille, 2007: 281). Ancak, bu iktisatçılar kurum analizini neoklasik iktisadın etkinlik ve verimlilik gibi kavramlarından hareketle yaptılar. 1980'lerde ortaya çıkan yeni iktisat sosyolojisi de kurumsal yapının analiz edilmesi gerekliliği üzerinde durmuş; ancak yeni kurumsal iktisatçıların aksine kurumların etkinlik ve verimlilik temelinde açıklanamayacağını ileri sürmüştür. 1980'lerde ortaya çıkan yeni iktisat sosyolojisi akımı ile birlikte 2000' li yıllardan itibaren Amerikan üniversitelerinde ekonomi sosyolojisi en popüler araştırma alanlarından biri haline gelmiştir. Ana akım geleneğinin en güçlü olduğu okullardan biri olan MIT 2006 yılında "Ekonomi Sosyolojisi" başlıklı doktora programı başlatmıştır. Yine anaakım geleneğin en güçlü olduğu okullardan olan biri olan Princeton, Yale, Michigan ve Stanford üniversitelerinde iktisat sosyolojisi ile ilgili doktora programları oluşturulmuştur. Son 20 y1l içinde ABD'deki üniversitelerde iktisat sosyolojisinin en revaçta olan ve genç araştırmacıların en fazla ilgisini çeken alanlardan biri haline geldiği görülmektedir (Özatalay, 2011: 66).

2 İktisadi emperyalizm terimi ilk olarak 1933 yllında Ralph William Souter tarafindan türetilmiştir (Fine ve Milokanis, 2014: 26). Ancak bu kavramın popüler olması Becker'la olmuştur. Becker (1990)'da “iktisadi emperyalizm yaptığımın muhtemelen iyi bir tanımıdır" diyerek iktisat emperyalizm nitelemesini kabul etmiştir (aktaran Fine ve Milokanis, 2014: 44). Fine ve Milokanis (2014), iktisat emperyalizmini "iktisadi analiz konusunun kendi geleneksel sinırlarının ötesine doğru genişlemesi" olarak tanımlamaktadır (Fine ve Milokanis, 2014: 30). 


\section{Weber ve Durkheim'ın İktisadi Sosyoloji Yaklaşımı}

19. Yüzyılın sonunda doğan iktisadi sosyoloji yaklaşımı temel olarak ekonomiyi toplumsal hayatın bir kısmı olarak görmüş ve iktisadi olayların arkasındaki sosyal nedenleri açıklamayı amaçlamıştır. Bu çerçevede, üretim, bölüşüm ve değişim süreçlerini sosyolojik bir bakış açısı ile ele almışıtır. 1830'larda sosyoloji biliminin kurucusu olarak bilinen August Comte zamanındaki İngiliz klasik iktisatçılarını çok soyut olmaları ve somut ampirik gerçeklerle ilgilenmemeleri nedeniyle eleştirmiştir. Comte, toplumsal olayların bir bütün olması nedeniyle birbirlerinden ayrı olarak incelenemeyeceğini ileri sürmüş; çağdaş iktisadi olayların analizi yapılırken hem mevcut hem de geçmişteki entelektüel, ahlaki ve politik gelişmelerin göz önünde bulundurulması gerektiğini ileri sürmüştür. Comte'a göre, iktisadi olayları toplumsal olaylardan yalıtılmış bir şekilde ele alan klasik politik iktisat iktisadi hayatla ilgili son derece sinırlı bilgiler üretiyor ve bu nedenle metafizik aşamadan öteye geçemiyordu ${ }^{3}$ (Kurmuş, 2009: 126). Bu nedenle, Comte sosyolojinin gelişimini tamamlayabilmesi için sosyal bilimlerin diğer alanlarıyla işbirliği içinde olmasına dikkat çekmiş; ancak sosyolojinin diğer bilimlere indirgenmesine karşı çıkmıştır. Comte, bireyi hareket noktası alan ve toplumu bireylerin toplamından ibaret gören yöntemsel bireyci yaklaşımı da güçlü bir şekilde eleştirmiştir. Çünkü, Comte temel gerçekliğin toplum olduğunu vurgulamış; toplumun teorik düzlemde bireye indirgenmesine karşı çıkmıştır. Comte'a göre toplumun incelenmesinde bütünden hareket edilmeli ve her bir parça bütünün ışığında ele alınmalıdır (Keat \& Urry, 2001: 122). Toplum Comte tarafindan "diğer fenomenlerin var olmasına veya dayanmasına neden olan gerçek bütünlükler" olarak görülmektedir (Keat \& Urry, 2001: 124).

19. Yüzyılın sonunda Emile Durkheim ve Max Weber gibi sosyologlar Comte'un bu eleştirisi üzerinden iktisadi sosyoloji yaklaşımını önermişlerdir (Swedberg \& Granovetter, 1992: 3). Bu nedenle iktisat sosyolojisinin doğuşunun Weber ve Durkheim'ın çalışmalarına dayandığını söyleyebilmek mümkündür. Bu bağlamda, Weber'in Protestan Ahlakı ve Kapitalizmin Ruhu (1905) ve Durkheim'ın Toplumsal İşbölümü (1893) başlıklı eserleri iktisadi sosyoloji yaklaşımının ilk örnekleri olarak nitelendirilmektedir. İktisatçılar arasında iktisat sosyolojisi kavramını ön plana çıkaran ve bu alana en fazla katkıda bulunanlar ise Schumpeter ve Polanyi olmuştur (Smelser \& Swedberg, 2005: 7-8).

3 Comte 1855 yllında yayınlanan "Positive Philosophy" başlıklı kitabında klasik iktisatçılarla ilgili aşağıdaki sözleri sarfetmektedir: bu kişiler "... bilimsel disipline sahip olmayan; ... bilimsel gözlem yapma yeteneğinden yoksun... sahip olduklart mantık ilkelerinin müphemliği yüzünden tümüyle metafizik kavramlar kullanan” kişilerdi. (aktaran Kurmuş, 2009: 126). 
Durkheim Sosyolojik Yöntemin Kuralları başlıklı kitabında sosyal olayların birer “şey” olarak incelenmesi gerektiğini ifade etmektedir. Durkheim “şey” ile "düşünceye karşıt olan"1 kastetmektedir4. Durkheim toplumsal olayların "şey”ler gibi alınabileceğini söylerken, Comte gibi fiziki dünya ile sosyal dünya arasında bir ayrım yapmamış; tek bir bütün olarak kabul ettiği dünyaya ait toplumsal ve doğal gerçekliğe ancak gözlem ve deney yoluyla ulaşılabileceğini belirtmiştir (Ercan, 1995: 133). Pozitivist bilim felsefesi ile önemli benzerlikler göstermekle birlikte Durkheim'ın bu yaklaşımını tümüyle pozitivist olarak nitelendirmek mümkün değildir. Durkheim, sosyal olanın daha karmaşık ve bu nedenle daha zor gözlemlenebilir olması nedeniyle evrensel sosyal yasalara ulaşmanın güç olduğunu düşünmektedir (Keat \& Urry, 2001: 132-3).

Durkheim sosyal kurumların büyük çoğunluğunun önceki kuşaklardan alındığını belirtmekte ve bu nedenle sadece bireye bakılarak kurumsal ve toplumsal davranışın açıklanmasının mümkün olmadığını kabul etmektedir. Toplumsal yapı içinde birey küçük bir yer tutmaktadır. Toplumda sadece bireylerden oluşmamaktadır. Toplumda bireylerin ötesinde, toplumun bütünleştirici unsurları olan “şey”ler vardır (Durkheim, 2014: 19). Dolayısıyla, Durkheim toplumun bireylerin toplamından ibaret olduğu yolundaki düşünceyi kabul etmediği gibi, bireyin sadece toplum tarafından belirlendiği ve dolayısıyla bireyin toplumsal yapı üzerinde her hangi bir etkiye sahip olmadığı yolundaki düşünceyi de kabul etmemektedir.

Durkheim sosyal olayların çeşitli düşünce ve davranış biçimlerine dayandığını belirtmektedir. Durkheim'a göre, kolektif bilinç durumları doğası gereği bireysel bilinç durumlarından farklı özelliklere sahiptir. Bu açıdan, grupların düşünce yapısı bireylerin düşünce yapısından farklı kendine özgü yasalara sahiptir. Bu nedenle, Durkheim toplumsal yaşamın sadece psikolojik etkenlerle açıklanamayacağını belirtmektedir. Bu açıdan, grubun bireyden farklı bir şekilde oluştuğuna ve bu nedenle her birinin farklı özneleri ve farklı nesneleri tanımladığına dikkat çekmektedir. Durkheim'a göre, farklı özne ve farklı nesnelere sahip olan bu iki unsur aynı nedenlere bağlı olamaz. Dolayısıyla, toplumu anlamak için bireylerin değil toplumun doğasının anlaşılması gerekmektedir (Durkheim, 2014: 20-1).

$\mathrm{Bu}$ düşünceler Comte gibi Durkheim'ın da yöntemsel bireyci yaklaşımı benimsemediğini göstermektedir. Bu çerçevede, Durkheim toplumun sadece kendi özel istek ve arzuları tarafından yönlendirilen bireyler topluluğuna indirgenemeyeceğini düşünmekte

"Doğal yollardan zihinsel olarak kavranamayan basit bir zihinsel analizle hakkında uygun bir fikir edinemediğimiz, zihnin yalnızca kendi dışına çıkmak koşuluyla, gözlem ve deney yoluyla, en dişsal ve kavranması en kolay niteliklerden başlayıp en görülmez ve en derindeki niteliklere ulaşarak anlayabileceği her bilgi nesnesi bir "şey"dir" (Durkheim, 2014: 15). 
ve toplumu bireylerin toplamından öte bir varlık olarak düşünmektedir. Dolayısıyla, bireysel davranışın açıklanması toplumsal davranışın anlaşılmasında yeterli olamayacaktır. Durkheim'ın gözünde kolektif düşünce ve davranış biçimlerinin kendine özgü bir özelliği bulunmaktadır. Birey bunları toplum içinde hazır bulmakta ve hesaba katmak zorunda olmakla birlikte birey bunların oluşumunda da etkilidir. Ancak, burada önemli olan tek bir bireyin davranışları değildir. Birçok bireyin kendi eylemlerini birleştirmesi ve bu eylemlerin yeni bir kuramsal yapıyı ortaya çıkarması gerekir (Durkheim, 2014: 26-7).

Durkheim her ne kadar yöntemsel bütüncül bir yaklaşımla toplum denilen varlığa öncelik tanısa da etik ve politik açıdan bakıldığında Durkheim bireyci bir yapıya da sahiptir. Durkheim'ın etik ve politik düzlemdeki bu yönü Durkheim 1893 yılında yayınlanan doktora tezi Toplumsal İşbölümüne Dair isimli çalışmasında açıkça görülmektedir: (aktaran Corcuff, 2009: 31-2).

"Bilinç hallerimiz büyük çoğunluğu yalıtılmış varlıklarda ortaya çıkmaz; başka biçimde gruplaşmış varlıklarda ise bambaşka biçimde ortaya çıkar. Dolayısıyla bilinç hallerimiz genel olarak insanın psikolojik doğasından değil, bir araya gelmiş insanların birbirlerini karşılıklı biçimde etkileme tarzlarından türerler... Bu noktada parçaların biçimi pekala bütünün biçimi tarafindan belirlenmektedir"

Yukarıdaki alıntıdan da anlaşılabileceği gibi, Durkheim toplumsal yapıların ve toplumun bireylerin düşünce ve eylemleri üzerindeki etkisinin önemli olduğunu düşünmekte ve sadece kendi çıkarını güden birey tipini kavramsallaştıran dar faydacı bireyciliği reddetmektedir. $\mathrm{Bu}$ şekilde, Durkheim bireyin toplumdan yalıtılmış bir varlık olarak kavramsallaştırılmasına karşı çıkmakta; bütün piyasaların ve mübadele ilişkilerinin geleneğin ve normların etkisi altında sosyal olarak düzenlendiğine işaret etmektedir. Durkheim, Comte'un sosyal olayların karşılıklı bağımlı olduğunu vurgulayarak sosyolojiye önemli bir katkı yapmakla birlikte sosyolojik bir analiz ortaya koyamadığına dikkat çekmiştir. Durkheim Comte'un açtığı yoldan giderek sosyolojiye "bir yöntem ve bir beden" vermeyi amaçlamıştır (Keat \& Urry, 2001: 135).

Weber iktisat sosyolojisinin bağımsız bir bilim dalı olarak ortaya çıkmasında etkili olan en önemli düşünürlerden biridir. Weber, ortaya koyduğu yaklaşımda üretim, tüketim, mübadele gibi temel iktisadi süreçlerin sosyal ve kültürel yönüne dikkat çekmiş; Durkheim gibi iktisadi olaylara ilişkin evrensel yasa bulma iddiasını reddetmiştir. Weber sosyal bilimleri "yaşam olgularını, bu olguların kültürel anlamı açısından ele alan bilim dalları" olarak tanımlamış ve sosyal bilimleri tanımlamak üzere "kültür bilimleri”" kavramını kullanmıştır (aktaran: Buğra, 2005: 190). Weber kültürü “değerlerle ilgili bir kavram” olarak tanımlamaktadır. Weber, her özgün olayın anlamını belirli bir değerler sisteminden aldığını 
düşünmekte ve bu nedenle sosyal bilimlere ilişkin nesnel bilgi üretiminden söz edilemeyeceğini belirtmektedir. Bu çerçevede, Weber'e göre sosyal bilimcinin nesnel bilgi üretiminden ve yasalardan ziyade her özgün olayın içinde yer aldığı çerçeveye göre biçimlenen anlamı ile ilgilenmesi gerekir (Buğra, 2005: 190).

$\mathrm{Bu}$ noktada, Weber sosyal bilimlerde değer yargılarından bağımsız bir bilim oluşturabilmenin olanaksızlığına dikkat çekmekte ve bu anlamda sosyal bilimlere ilişkin evrensel ve mutlak yasalar oluşturmanın mümkün olmadığını ileri sürerek pozitivist düşünceye karşı çıkmaktadır. Bu bağlamda, sosyal bilimcilerin soyut ve evrensel olan değil, somut ve özgün olan üzerinde durması gerektiğine işaret etmektedir. Weber somut olaylarla ilgili anlamın ortaya çıkarılması ile esas olarak bir açıklama sorunundan değil bir yorumlama sorunundan bahsetmektedir. Weber'in yorumlama süreci "sezgi yoluyla, "kendi değerlerine atıfla anlamak" (verstehen)tan geçen bir süreçtir. Ancak, Weber sezgisel bilginin önemini vurgulamakla birlikte sosyal bilimcinin tek kaynağının sezgisel bilgi olduğunu düşünmemektedir. Weber'e göre, niceliksel çözümlemeler ve istatistikler yardımıyla ortaya çıkartılacak nedensellik ilişkileri ile verstehen yoluyla ortaya atılan hipotezler kanıtlanmalıdır. Diğer bir deyişle, Weber iki yöntemin de sosyal bilimler açısından önemli olduğunu belirtmektedir (Buğra, 2005: 190-1). Bununla birlikte, Weber Durkheim'ın aksine kültürel yapı ve değerlerin öneminin altını çizmiş ve bu unsurlar nedeniyle toplumsal olayların "şey”ler olarak alınamayacağını ileri sürmüştür. Bu nedenle, Weber'in Durkheim ile karşılaştırıldığında pozitivizme karşı daha mesafeli bir çizgide bulunduğunu söylemek mümkündür.

Weber tarihselciler ile Avusturya iktisatçıları arasında yaşanan yöntem kavgasında orta yolcu bir yorum getirmiştir. Weber bir yandan tarihsel okulun yetersizliklerine dikkat çekmiş; diğer yandan da pozitivizmi ve dolayısıyla marjinalizmi güçlü bir şekilde eleştirmiştir. Weber ortaya attığı sosyo-ekonomi yaklaşımı ile tarihsel, kültürel ve ekonomik faktörler üzerine vurgu yapmış; ancak ekonomik ve toplumsal meseleler analiz edilirken nesnel ve neden sonuç ilişkisine dayanan bir yöntemin gerekliliğine dikkat çekmiştir. Weber'e göre sosyal bilimcinin araştırma sürecinde değer yargılarının çok büyük bir önemi bulunmaktadır. Ancak, Weber nesnenin açıklanma sürecinde bu değer yargılarının devre dışı bırakılması gerekmektedir. Weber'e göre değerlerin ampirik bilimin araçlarıyla kanıtlanabilmesi mümkün değildir. Araştırma sürecinde kategorik olarak birbirinden ayırt edilmesi gereken iki bilgi türü bulunmaktadır. Bu çerçevede, biri genel kavramlarla diğeri ise incelenen olgunun kültürel anlamı ile ilgilidir (Weber, 2012: 13). Weber'e göre, ekonomik eylemleri etkileyen tüm politik, sosyal ve hukuksal yapıların da bilimsel ilgiyle ilişkileri ölçüsünde iktisadi analize dahil edilmesi gerekir. Bu açıdan, teorik inşaların gerçekliğin bilgisine varmaya yardımcı olmanın ötesinde bir işlevi yoktur (Weber, 2012: 72). 
Weber'e göre, marjinalist iktisadın başlangıç noktası, iktisadi çıkarlarını rasyonel olarak takip eden pür bir rasyonel iktisadi eylem teorisine dayanmaktadır. Fakat, Weber'in eylem tipolojisi rasyonel iktisadi eylemi sosyal eylemin muhtelif çeşitlerinden yalnızca biri olarak sınıflandırmaktadır. Bu noktada, Weber üç tür rasyonel eylem olduğuna dikkat çekmektedir: Bunlar, amaca yönelik rasyonel eylem, değere yönelik rasyonel eylem, geleneksel ve duyusal eylem biçimleridir. Weber'e göre amaca yönelik rasyonel eylemde, birey amacının ve bu amaca ulaşmak için seçtiği araçları bilmektedir. Burada, birey herhangi bir değer olmaksızın kendi istediği doğrultuda amaçlı bir rasyonel seçim yapmaktadır. Değere yönelik rasyonel eylemde, eylem bir değer doğrultusunda bilinçli bir şekilde yapılmaktadır. Geleneksel eylem, gelenek ve inançlara bağlı olarak alışkanlık haline gelmiş uygulamaları ifade etmektedir. Son olarak, duygusal eylem ise bir uyarı ile meydana gelen eylem biçimini ifade etmektedir (Ercan, 1995: 137-8). Weber'e göre, sosyal bilimlerin dallarından biri olan iktisat ideal tip olarak nitelenebilecek rasyonel iktisadi eylem sergileyen bireylere dayanmaktadir ${ }^{5}$ (Y1lmaz, 2002-3: 70).

Weber'e göre, psikolojik ve sosyal olaylarla uğraşan her bilim bir insan davranış1 bilimidir. Bu bilimler davranışı "anlama" ve daha sonra "yorumlayıcı" bir biçimde açıklamakla ilgilenirler. İdeal tipler bu "anlama" sürecinde önemli bir işlev görürler (Weber, 2012: 67). Ampirik olaylara nedensel açıklama getirmek için bir düşünce ya da davranış örüntüsünün rasyonel, ampirik ve mantıksal doğruluğa ve tutarlılığa tamamen sahip olması durumunda neye benzeyeceğine dair soruların sorulması gerekir. Bunun için, rasyonel, ampirik ve teknik ve mantıksal yapıların kurulmasına gerek bulunmaktadır (Weber, 2012: 69). Weber'e göre, ideal tipin araştırmadaki işlevi ampirik gerçekliğin ayrıştığı ya da benzeştiği yerlerin belirlenmesi ve bunların en anlaşılabilir kavramlarla tanımlanmasıdır. İncelenen olguyu nedensel olarak anlamak ve açıklamak için ideal tipler söz konusu ampirik gerçeklikle karşılaştırılır. Weber ideal tiplerin iktisat teorisinde yoğun bir şekilde kullanıldığını belirtmektedir. Bu çerçevede, iktisat teorisinde "insanların eylemleri eğer tam anlamıyla rasyonel olsaydı, bu varsayılan koşullar altında nasıl davranırlardı?" sorusu çerçevesinde saf iktisadi çıkarların var olduğu varsayılır ve iktisadi olmayan bütün diğer unsurlar dışarıda bırakılır. Weber'in saf iktisat olarak nitelendirdiği neoklasik iktisat ideal bir tip olarak analitik açıdan önemli yararlar sağlayabilir. Weber için sorun neoklasik

5 Weber ideal tip kavramını önemli bir analiz aracı olarak kullanmaktadır. Weber'in analizinde ideal tipler, toplumsal gerçeklikle bütünleşen ve onu kapsayan bir şey değildir. Weber bu tiple toplumdaki ortalama tipleri de kastetmemektedir. Weber üç tip ideal tipin görülebileceğinden bahseder. Bunlardan birincisi, tarihsel ideal tipler tarihsel süreç içinde bir defa ortaya çıkan tekil olgulardır. Protestan etik tarihsel ideal tipin tipik bir örneğidir. İkinci olarak, belirli davranışlar olarak ideal tiplerdir. Rasyonel ekonomik insan bunun bir örneğini oluşturmaktadır. Ü̧̧üncü olarak da toplumsal gerçekliğin elemanı olan ideal tipler bürokrasi ve feodalizmi de buna örnek olarak vermektedir (Ercan, 1995: 140). 
iktisadın gerçekliğin aslına uygun bir resmi olarak kavranması ve "geçerli bir normatif ideal" olarak görülmesidir (Weber, 2012: 70-71).

1930 sonrası dönemde marjinalist akımın yükselmesiyle birlikte iktisat teorisinde yaşanan gelişmeler Weber ve Durkheim tarafından temelleri atılan iktisadi sosyoloji yaklaşımının gözden düşmesine neden olmuştur. Marjinal analizin yükselmesi yani iktisadın kendi sınırlarını belirlemesi sosyolojinin de bağımsız bir disiplin olarak ortaya çıkmasına zemin hazırlamıştır. Literatürde Robbins ve Parsons uzlaşısı olarak bilinen bir uzlaşıyla hem iktisadın hem de sosyolojinin alanları kesin çizgilerle tanımlanmıştır. 1970'li yıllara kadar kabul gören bu uzlaşının sonucu olarak bu iki disiplin arasında çok az iş birliği yapılmıştır (Yılmaz, 2012: 3). Bu süreçte ortodoks iktisatçılar kurumlara ve sosyal hayatın iktisadi olmayan yönlerine ilgi duymamışlardır.

\section{Yeni İktisat Sosyolojisi: Kapsam, Temel İlkeler ve Eleştiriler}

1960'lar boyunca ABD'de iktisat ve sosyoloji disiplinleri arasındaki ayrım giderek daha kesin hale gelmiştir. Bu süreçte sosyologların iktisadi konulara ve iktisatçıların da sosyal konulara ilgisinin ciddi bir şekilde azaldığı görülmektedir. Ancak, 1970’li yıllardan itibaren neoklasik iktisadın daha önce sosyolojinin alanına girerek göz ardı ettiği konuları inceleme altına almaya başlamasıyla birlikte sosyologların neoklasik iktisadın hegemonyasına karşı gösterdikleri tepki yeni iktisat sosyolojisinin doğmasına zemin hazırlamıştır. Bunun sonucu olarak iktisatçılar ve sosyologlar arasında yeni bir ilişki kendini göstermeye başlamıştır. Bu ilişkide, bazı iktisatçılar iktisadın bazı alanlarının sosyoloji yardımıyla geliştirilebileceğini düşünürken; Akerlof (1984), Olson (1965) ve Becker (1976) gibi iktisatçılar sosyolojik problemlerin iktisadi yaklaşım kullanılarak çözülebileceğini ileri sürmüşlerdir. $\mathrm{Bu}$ ikinci gruptaki iktisatçılar rasyonel seçim mantığının sosyolojiye uygulanması gerektiğini ileri sürmüşlerdir. Bunların dışında bir takım sosyologlar ise iktisat ve sosyoloji bakış açısının bir karışımını önermişler ve her iki alandan da faydalanılması gerektiğini ileri sürmüşlerdir. Bu gelişmeler daha önce kesin çizgilerle ayrılan iktisat ve sosyoloji disiplinleri arasındaki sınırın genişlemesine neden olmuştur. Bu süreçte iktisatçılar esas olarak yeni kurumsal iktisat, sosyologlar ise iktisadi hayatın yeni sosyolojisi olarak da isimlendirdikleri yeni iktisat sosyolojisi izini takip etmişlerdir (Swedberg, 1991: 265-6). Bu şekilde yeni iktisat sosyolojisi iktisadın emperyalizmine karşı olarak sosyologların önceden çözmek için iktisatçılara bıraktıkları ekonomik problemleri analiz etmeyi amaçlamıştır. Bu çerçevede, ekonomik ağların rolü, iktisadi organizasyonların yapısı ve iktisadi hayatta kurumların rolü gibi alanlara odaklanmışlardır. (Swedberg, 1991: 251).

Yeni iktisat sosyolojisi teriminin ilk kez kullanıldığı yer olan Granovetter'ın 1985 y1lında yayınlanan "Economic Action and Social Structure: The Problem of Embeddedness" başlıklı makalesi çağdaş sosyolojinin en önemli makalelerinden biri olarak kabul 
edilmektedir. Granovetter bu makalede yeni kurumsal iktisada çok sert eleştiriler yöneltmiştir. Bu eleştirilerden en önemlisi, yeni kurumsal iktisatçıların kurumların ortaya çıkma nedenini etkinlik ve verimlilik gibi kavramlarla açıklamalarıdır. Granovetter'a göre mevcut iktisadi kurumların en etkin çözümü yansıtmaları nedeniyle ortaya çıktıkları yolundaki düşünce doğru değildir ${ }^{6}$. Bu nedenle Granovetter, yeni kurumsal iktisadın kurumların analizini sosyolojik, tarihsel ve yasal tartışmalardan saptırılmasına neden olduğunu ve kurumların varlığını "iktisadi problemlere etkin çözümler üretmek" olarak özetlenebilecek son derece indirgemeci bir bağlamda açıkladığını ileri sürmektedir. Granovetter, böyle bir analiz tarzının son derece yetersiz olduğunu; kurumların ortaya çıkışını ve işlevlerini anlamak için sosyal yapının çok daha detaylı bir şekilde analiz edilmesi gerektiğini ileri sürmektedir. Granovetter, yeni kurumsal iktisatçıların neoklasik iktisada yönelik eleştirilerinin genel olarak rasyonalite ve etkinlik kavramları temelinde yapıldığını; oysa iktisadın sosyal yapıyı analize katma başarısızlığı üzerinden yapılan eleştirilerin çok daha verimli olabileceğini belirtmiştir (Swedberg, 1997: 162).

Granovetter makalesinde daha önce Polanyi tarafından kullanılan "gömülülük" (embeddedness) kavramını kullanarak iktisadi alanın toplumsal, kültürel ve politik süreçler içerisine gömülü olduğuna işaret etmiştir. Bu kavram, iktisadi faaliyetlerin sınıf, güç, siyaset, kurumlar, kültür gibi sosyal yapı ve ilişkilerin içinde gömülü olduğunu ifade etmektedir. Granovetter'a göre, bu ilişkiler iş adamlarının, yöneticilerin, girişimcilerin, çalışanların piyasalardaki davranış biçimini önemli ölçüde belirlemektedir. Dolayısıyla, Granovetter iktisadi davranışın yalnızca kar ve maliyet hesaplamasıyla yapıldığı yolundaki düşünceyi reddetmekte ve iktisadi davranışın bireysel rasyonel hesaplamaya indirgenmesine karşı çıkmaktadır (Kabaş, 2013: 17). İktisadi eylem sadece iktisadi unsurları değil, iktisadi olmayan unsurları da içerir. Granovetter 1992 yılında yayınladığı "Economic Institutions as Social Constructions: A Framework for Analysis” isimli makalesinde gömülülük kavramını kullanarak "yeni iktisat sosyolojisi”nin temelini oluşturan üç unsurdan bahsetmektedir. Bunlardan birincisi iktisadi faaliyetler toplumsal ilişkiler ağı içine gömülüdür. İkincisi, iktisadi faaliyetler sosyal oluşumlardır. Bu nedenle, iktisadi eylemlerin sadece bireysel güdülerle açıklanabilmeleri mümkün değildir. Üçüncü olarak da, iktisadi kurumlar toplumsal oluşumlardır (Granovetter, 1992: 4). Bu çerçevede yeni iktisat sosyolojisinde

6 Bilindiği gibi, yeni kurumsal iktisatçılar Amerikan kurumsalcılı̆̆ ile oldukça farklı bir analiz yapısına sahiptirler. Yeni kurumsal iktisatçllar asimetrik bilgi, işlem maliyetleri ve vekil problemleri gibi konulara vurgu yaparak kurumların yapısını ve varlı̆̆ını ve işlem maliyetlerinin nasıl minimize edileceği üzerinde dururlar. Yeni kurumsal iktisatta kurumların ortaya çıkışı işlem maliyetlerinin minimize edilmesi ile açıklanır. Buna göre, bir organizasyonun diğerine tercih edilmesinin temel nedeni etkinlik ya da verimliliktir. Bu yeni iktisadi sosyoloji yaklaşımın yeni kurumsal iktisattan ayıran temel unsurlardan biridir. Yeni iktisat sosyolojisi kurumların varlı̆̆ının sadece etkinlik ve verimlilik ile açıklanamayacağını belirtir (Swedberg, 1991: 265-6). 
gömülülük kavramı kadar önemli bir diğer kavram da "ekonominin toplumsal oluşumu" kavramıdır. Bu kavram kurumların toplumsal oluşumlar olup, otomatik olarak ortaya çıkmadıklarını ifade etmektedir ${ }^{7}$. Bu çerçevede, Granovetter insan eylemi ve kurumlar arasındaki ilişkinin birbiri ile taban tabana zıt iki teori ile açıklandığını belirtmektedir. $\mathrm{Bu}$ teorilerden biri "aşırı sosyalleşmiş" bir insan eylemi anlayışına sahiptir. Sosyoloji alanında yaygın bir şekilde kabul edilen bu yaklaşımda bireyin toplum tarafından biçimlendirildiği düşünülmektedir. Diğerinde ise, birey son derece atomize, yalıtılmış ve toplumdan bağımsız bir varlık olarak tanımlanmakta ve insan eylemi bütünüyle iktisadi alanla açıklanmaktadır (Granovetter, 1990: 97). İktisadın dayandığı rasyonalite kavramı ve iktisadın realistik olmayan doğası Granovetter'ın vurgu yaptığı diğer konular arasındadır. (Baş Dinar, 2013: 46).

Yeni iktisat sosyolojisi faydayı maksimize etmek biçiminde tanımlanan rasyonel davranış varsayımını eleştirmektedir. Bu bağlamda, toplumda yalıtılmış sadece kendi çıkarlarını düşünen bir insan yerine insanı içinde yaşadığı toplumun bir parçası olarak görmektedir. Buna göre, insanın içine doğduğu karmaşık sosyal yapı bireyin davranışlarını belirlemektedir. Bu nedenle, sosyal yapıların sadece bireysel davranışlardan yola çıkılarak açıklanabilmesi mümkün değildir. Bireysel davranış toplumsal ilişkiler ağı içine gömülüdür. Burada, ağlar ile bireyler arasındaki düzenli ilişkiler seti kastedilmektedir. A ̆g içerisinde bulunan bir bireyin sosyal davranışı, grup içerisindeki diğer bireylerin davranışlarından etkilenmektedir (Kabaş, 2013: 17). Bu karşılıklı etkileşim iktisadi analizin basit ve mekanik bir şekilde ele alınmasına engel olmaktadır. Çünkü bu yaklaşımda iktisadi davranışın çok uzun bir karşılıklı etkileşimin sonucu olarak ortaya çıktığı ileri sürülmektedir (Swedberg \& Granovetter, 2001: 11). Bu çerçevede, yeni iktisat sosyolojisine göre klasik ve neoklasik iktisat rasyonaliteye aşırı önem vermekte ve kültürün rolünü göz ardı etmektedir. Oysa kültür iktisadi yapıyı etkileyen önemli bir faktördür. Kültür toplumların değerlerini biçimlendirerek neyin normal neyin sıra dışı kabul edilebileceği konusundaki yargıları biçimlendirmektedir.

Yeni iktisat sosyolojisi yaklaşımında toplumdaki bireylerin birbirinden izole değil tam tersine birbirlerine ilişkiler ağı içinde bağımlı olduğu düşünülür. Bu çerçevede, yeni iktisat sosyolojisinde cinsiyet, etnik kimlik gibi farklılıkların bireylerin davranışlarının belirlenmesinde oldukça etkili olduğu ve bu tür farklılıkların iktisadi analize dahil edilmesi

7 Swedberg (1997) ekonominin bir sosyal kurulum olduğu yolundaki fikrinin Granovetter'in 1985 yllındaki makalesinde olmadı̆̆ına; bu fikre makalenin daha sonraki versiyonlarında (1986-7) yer verildiğine dikkat çekmektedir (Swedberg, 1997: 165). 
gerektiği ileri sürülmektedir. Ayrıca, bu yaklaşımda bireylerin eylemlerinin sadece iktisadi sonuçlarının değil iktisadi olmayan sonuçlarının da önemli olduğuna dikkat çekilmektedir.

Sosyal olana yaptıkları vurgu ve neoklasik iktisatçıların analizlerine yönelttikleri eleştiriler konusunda yeni iktisat sosyolojisi yaklaşımı iktisadi sosyoloji yaklaşımı ile bir takım benzerliklere sahiptir. Ancak, neoklasik iktisadı eleştirmek ve sosyal olana vurgu yaparak analizi daha gerçekçi bir şekilde yapmayı amaç edinmekle birlikte yeni iktisat sosyologlarının çalışmalarına bakıldığında neoklasik iktisadın yöntemini ve kavramlarını kullanarak neoklasik iktisadın pozitivist yapısını benimsemeye devam ettikleri görülmektedir. $\mathrm{Bu}$ çerçevede, yeni iktisat sosyolojisinin toplumsal olanı son derece indirgemeci bir şekilde tanımladığı ve toplumsalı ă ilişkileri sistemine indirgediği görülmektedir. Ayrıca, yeni iktisat sosyolojisi toplumsalı ele alırken tarihsel yapılara önem vermemektedir. Bu açıdan, yeni iktisat sosyolojisi neoklasik iktisadın tarih dışı yaklaşımını sürdürmeye devam etmektedir. Ayrıca, neoklasik iktisatta olduğu gibi analiz birimi olarak bireyi çıkış noktası olarak ele almakta ve bu anlamda yöntemsel bireyci bir yaklaşımı benimsemektedir.

Yeni iktisat sosyolojisine yöneltilen en temel eleştirilerden biri sosyologların iktisat teorisi ile iş birliği yapmaları ve iktisat tarihi ile bağlarını kopartmalarıdır (Swedberg, 1991: 270-2). Tarihle iktisat arasında yapılacak bir iş birliği iktisadın gerçekçi bir bilim olması açısından son derece önemlidir. Toplumsal yapılar sürekli olarak evrilmekte ve değişmektedir. Toplumu inceleyen yaklaşımların evrim ve değişme unsurunu göz önünde bulundurması gerekir. Bu özellikleri itibariyle toplumun mutlak yasalarla açıklanabilmesi mümkün değildir. 20. Yüzyılda ortaya çıkan yeni iktisat tarihi, yeni iktisat sosyolojisi ve yeni kurumsal iktisat gibi yaklaşımlar toplumu ve ekonomiyi özü itibariyle mekanik bir mantıkla incelenebilecek doğrusal bir süreç olarak almaya devam etmektedirler. Karmaşık bir gerçekliğin anlaşılması için karmaşık bir açıklama gereklidir. Bu nedenle, bu yaklaşımlar toplumsal ve ekonomik hayata dair tatmin edici açıklamalar getirebilme olasılığını sınırlamaktadır (Freeman \& Louça, 2013: 4-5).

Yeni iktisat sosyolojisi her ne kadar toplum ve ekonomi arasındaki içsel bağımlılığa çok fazla vurgu yapmış olmakla birlikte sosyal olmayan bir piyasa görüşüne sahiptir. Calnitsky bundan dolayı yeni iktisat sosyolojisinin merkezi kavramının gömülülük değil dengesizlik olduğuna dikkat çekmekte; bu açıdan bakıldığında yeni iktisat sosyolojisinin neoklasik iktisadın bir dalı olarak görülebileceğine işaret etmektedir. Calnitsky’ye göre, yeni iktisat sosyolojisi ile ilgili temel sorun çok sık tartışıldığ gibi gömülülük kavramının değil yeni iktisat sosyolojisinde kullanılan sosyal ilişkiler kavramının belirsizliğinden kaynaklanmaktadır. Yeni iktisat sosyolojisinde sosyal ilişkiler kavramı ile üretim araçlarına kimin sahip olduğu, emeğin faaliyetlerini kimin kontrol ettiği gibi kapitalist sosyal ilişkilerin temelini oluşturan ilişkiler değil, sözleşme ve arkadaşlık, 
akrabalık vb. kişisel düzeydeki ilişkiler ifade edilmektedir (Calnitsky, 2014: 567). Bu açıdan, yeni iktisat sosyolojisi toplumsal ilişkiler kavramını son derece indirgemeci bağlamda kullanmaktadır. Yeni iktisat sosyolojisinde bu kavram kapitalist üretim ve bölüşüm ilişkilerinin bir sonucu olarak ortaya çıkan bir ilişkiselliği ifade etmemektedir. Yeni iktisat sosyolojisinin bu yaklaşımı piyasa ilişkilerinin veri kabul edilmesine ve piyasa ilişkilerini ortaya çıkartan toplumsal ilişkiselliğin göz ardı edilmesine yol açmaktadır. Bu çerçevede, yeni iktisat sosyolojisinin toplumsalı son derece indirgemeci bir şekilde ele aldığını ve toplumsal ilişkileri piyasa ilişkilerine indirgediğini söylemek mümkündür.

Neoklasik iktisatta fiyat mekanizmasının ekonomiyi dengeye yönelttiği ve bu anlamda dengenin kaçınılmaz olduğunu ileri sürülmektedir. Yeni iktisat sosyolojisi ise fiyat mekanizmasının denge sağlayamadığı ve iktidar ilişkilerinin ve çıkar çatışmalarının var olduğu dengesizlik durumunu incelemektedir. Bu açıdan, neoklasik iktisatçılar bir takım varsayımlardan hareketle ekonomiyi dengeye yönelten güçleri analiz ederken, yeni iktisat sosyolojisi ise bu varsayımların geçerli olmadığı durumlarda ekonomiyi dengeden uzaklaştıran süreçleri analiz etmektedir. Bu bağlamda, neoklasik iktisat dengeye yeni iktisat sosyolojisi ise dengesizliğe vurgu yapmaktadır (Calnitsky, 2014: 566-8). Bu noktada, toplum ekonomide dengesizlik yaratan bir faktör olarak görülmektedir. Calnitsky’e göre, neoklasik iktisatçıların ve yeni iktisat sosyologlarının yaklaşımları bir madalyonun iki yüzü gibidir. Her iki yaklaşımdaki teorik farklılıklara yol açan temel şey farklı varsayımlardan hareket etmeleridir. Yeni iktisat sosyolojisi neoklasik iktisadın varsayımlarını esnetmekte ve bu varsayımların geçerli olmadığı durumları analiz ederek neoklasik iktisatçıların analizini gerçek hayata biraz daha yakın hale getirmektedir (Calnitsky, 2014: 566-8).

K1saca ifade etmek gerekirse, yeni iktisat sosyolojisi her ne kadar iktisadın sosyal bilimleri istila etmesine bir tepki olarak ortaya çıkmış olsa da kendisi de bunun bir parçası olmuştur. Yeni iktisat sosyolojisi eski iktisat sosyolojisi geleneğinin değil ana akım iktisadın bir sürdürücüsü haline gelmiştir. Yeni iktisat sosyolojisini eskisinden ayıran en önemli farklılık yeni iktisat sosyologlarının gömülülük kavramına ve toplumsal ağlara vurgu yapmalarıdır. İktisat sosyolojisinin öncüllerinde bu kavramlar merkezi bir konumda değildir. Ayrıca, eski iktisadi sosyoloji geleneği makro düzeydeki sistemik yapılarla ilgilenirken yeni iktisat sosyolojisi ilgisini mikro sosyal ilişkilere yöneltmiştir. Bunu en belirgin şekilde Weber'in kapitalizme ilişkin yaptığı analizlerde görmek mümkündür. Yeni iktisat sosyolojisinde sistemle ilgili yapısal analizlerden çok ağ analizlerine vurgu yapılmaktadır. Bu çerçevede, ağlar göreli olarak kısa bir zaman içindeki bireyler ya da küçük gruplar arasındaki ilişkileri ifade etmektedir. Büyük yapılar ve uzun süreçler ise yeni iktisat sosyolojisinin ilgi alanı içinde değildir. Eski iktisadi sosyoloji yaklaşımındaki temel teorik amaçlardan biri tarihsel bir sosyal sistem olan kapitalizmin incelenmesidir (Arrighi, 2001: 107). Dolayısıyla, eski iktisadi sosyolojiden yeni iktisat sosyolojisine iktisadın konusunda önemli bir değişiklik gerçekleşmiştir. İktisadın daha gerçekçi bir bilim haline gelebilmesi için ekonomik, sosyal ve kültürel faktörlerin göz önünde bulundurulduğu ve sınıf 
dinamiklerinin analiz edildiği daha çoğulcu bir çerçeveye gereksinim duyulmaktadır. Bu anlamda, iktisadi sosyoloji geleneğinin yeni iktisat sosyolojisine önemli bakış açıları kazandırabileceği söylenebilir.

\section{Sonuç}

Yeni iktisat sosyolojisi köken olarak iktisadi sosyoloji yaklaşımından etkilenmekle birlikte 1980 sonrası ciddi bir şekilde farklılaşmıştır. Başlangıçta iktisatçıların sosyal bilimler üzerindeki hakimiyetine tepki olarak ortaya çıkmakla birlikte yeni iktisat sosyolojisi zaman içinde iktisadın metodolojik emperyalizmine katkıda bulunmuştur. Sosyologlar zamanla iktisatçıların kullandıkları kavram ve argümanlar ile iktisadi olayları analiz etmeye başlamışlardır.

Yeni iktisadi sosyoloji yaklaşımı gömülülük kavramını kullanarak iktisadi eylemi toplumsal ilişkiler ağı içinde değerlendirmekle birlikte neoklasik iktisadın kavramlarını ve mantığını uygulamaya devam etmektedir. Dolayısıyla, yeni iktisat sosyolojisi neoklasik iktisadın ekonomik indirgemeciliğini sosyal bilimlerin diğer alanlarına doğru yaygınlaştırmaktadır. Bu açıdan, yeni iktisat sosyolojisi kapsamı oldukça geniş bir şekilde çizilen iktisadi sosyoloji yaklaşımının alanını daraltmaktadır. Oysa Weber ve Durkheim tarafından ortaya konulan iktisadi sosyoloji yaklaşımı sosyal bilimlerin bir bütün olarak kavranmasını önermiş; ekonominin toplumsal alandan ayrıştırılmasına karşı çıkmıştır.

Yeni iktisat sosyolojisine yöneltilebilecek en önemli eleştirilerden bir diğeri de neoklasik iktisadın yöntemsel bireyciliğini sürdürmesidir. Buna karşın, Weber ve Durkheim tarafından kapsamı belirlenen iktisadi sosyoloji yaklaşımı toplumu bireysel eylemlerin toplamının ötesinde bir olgu olarak kavramsallaştırmakta ve toplumu başlangıç noktası olarak kabul etmektedir. Bu çerçevede, iktisadi sosyoloji yaklaşımı toplumsala yaptığı vurgu ile birlikte yöntemsel olarak bütüncül bir yaklaşımı benimsemektedir. Oysa yeni iktisat sosyolojisi analiz birimi olarak bireyi kabul ederek bireysel davranışlardan ve ilişkilerden yola çıkmaktadır. Bu tür bir birey anlayışında birey toplumdan önce gelmekte ve bireyin toplumsallaşmışlığı göz ardı edilmektedir. Bireyin merkeze alınması toplumun analiz edilebilmesi açısından bir takım sıkıntılar oluşturmaktadır. Çünkü iktisadi ve toplumsal hayatı çevreleyen sorunlar esas olarak toplumsal ve ekonomik yapıdan kaynaklanmaktadır. Dolayısıyla, söz konusu toplumsal ve ekonomik sorunlara çözüm getirilebilmesi ancak toplumun inceleme nesnesi haline getirilmesi ile mümkün olabilmektedir.

Yöntemsel bireyci yaklaşımın bir başka sınırlaması da bu yaklaşımın ardında olan dışsal ilişkiler felsefesi ile açıklanabilir. Bu felsefi gelenekte parçalar arasındaki ilişkinin sonradan kurulabildiği ve incelenen her parçanın bütünü oluşturan diğer parçalarla ilişkisini kendi bünyesinde taşımadığı düşünülmektedir. Dolayısıyla, bu gelenekte gerçeklik "ilişki”, 
olarak değil "şey" olarak kavramsallaştırılır. Bu anlayışta, parça ön plana çıkartılarak toplum, ilişkili olduğu her şeye dişsallaştırılır (Atılgan, 2015: 72). Yöntemsel bireyci yaklaşımda birey merkeze alınmakla birlikte bireyin oluşumunda rol oynayan toplumsal, ekonomik ve siyasi koşullar dışarıda bırakılmaktadır. Böyle bir yaklaşımda toplum ve insan arasındaki ilişki görmezden gelinmekte ve birey toplumun ilişkisel bir parçası olarak kavranmadığı için yanlış biçimde tanımlanmaktadır. Bu kavramsal ve soyut bir birey ve toplum anlayışına yol açmaktadır ${ }^{8}$. Yöntemsel bireycilik bir soyutlama olarak toplumun ve ekonominin nesnel işleyiş koşullarını bilmek ve bunları anlamlandırmak ve yorumlamak konusunda önemli katkılar sağlayabilir. Weber'in ideal tip olarak tanımladığı bu tür teorik incelemeler yararlı olmakla birlikte ekonomik ve toplumsal ilişkilerin üretildiği tarihsel ve toplumsal bağlamı dıșarıda tuttuğu için yetersizdir. Politika, iktisat, toplumsal yapı ve kültür o kadar iç içe geçmişlerdir ki birbirlerinden ayrı bir biçimde anlaşılabilmeleri mümkün değildir (Gülbenkian Komisyonu, 2004: 10).

Görüldüğü gibi, yeni iktisat sosyolojisi neoklasik iktisadın yöntemsel bireyci yaklaşımını sürdürmekte ve iktisadın indirgemeci mantığının toplumsal olanı açıklamak için de kullanılması ile birlikte sosyal bilimlerin toplumsal sorunları tespit etme ve bunlara çözüm bulabilme yeteneğini önemli ölçüde sınırlandırmaktadır. Sonuç olarak, insanı ve toplumu açıklamaktan uzak analitik kurguların üretilmesine neden olmaktadır. Günümüzde 2008 krizi sonrasında ortaya çıkan toplumsal tepkiler bunun bir göstergesidir. İktisat kendi mantığını diğer toplumsal bilimlere uygulayarak diğer sosyal bilimlerin de kısırlaşmasına neden olmaktadır.

Yeni iktisat sosyolojisi toplumsalı gündeme getirme konusunda neoklasik iktisada göre daha ileride sayılmakla birlikte toplumsalı doğru bir biçimde ele almamaktadır. Bunun için toplumsal olanın daha gerçekçi bir biçimde yeniden tanımlanması ve iktisadi yaklaşımın böyle bir toplumsal analiz üzerinden yeniden inşa edilmesi gerekir. Bu nedenle, Weber ve Durkheim tarafından kapsamı çizilen iktisat sosyolojisi geleneğinden beslenen; kapitalizmi analiz eden, toplumsal sınıfları ve toplumsal sınıflar arasındaki etkileşimi göz önünde bulunduran, bireyden değil toplumdan hareket eden, tarihsel analizle yakın işbirliği içinde bulunan yeni bir iktisadi sosyoloji geleneğine ihtiyaç duyulmaktadır. Bu anlamda, ekonomi politiğin çok boyutlu bir yapı içerisinde toplumsal, tarihsel, iktisadi ve politik olanın göz önünde bulundurulduğu bir yapı içerisinde yeniden kurulması gerekmektedir.

Oysa, Marx'ın benimsediği içsel ilişkiler felsefesinde toplum basit bir şekilde ele alınmaz. Toplumun "ilişkisel”" olarak kurgulanmış olduğu düşünülür. Bu çerçevede, Ollman'ın ifadesiyle "sermaye, emek, değer ve meta, vs. 'nin hepsi, kendilerine dışarıdan bağlı olarak görme eğiliminde olduğumuz parçalarl, varlıklarının içsel unsurları olarak bünyesinde barındıran birer ilişki olarak anlaşılırlar” (Ollman, 2012: 44). 


\section{Kaynakça}

Arrighi, G. (2001), "Braudel, Capitalism, and New Economic Sociology”, Fernand Braudel Center Review, 24(1): 107-23.

Atılgan, G. (2015), “Diyalektik Bir Anayasa İncelemesi İçin Çerçeve Girişimi”, Ankara Üniversitesi SBF Dergisi, 70(1): 65-110.

Baş Dinar, G. (2011), "Veblen'in İktisadi Analizinde Sosyo Ekonomik Evrim ve Darwinizm”, içinde: M. Kaymak \& A. Şahinöz (Eds.) Darwin ve Evrimsel İktisat Sempozyumu, Ankara, Hacettepe Üniversitesi Yayınları.

Baş Dinar, G. (2013), “Kurum, İçü̈dü ve Alışkanlık Kavramları Temelinde Veblen'in Kurumsal Evrim Teorisi", Amme İdaresi Dergisi, 4(46): 45-66.

Buğra, A. (2005), İktisatçılar ve İnsanlar, İstanbul: İletişim Yayınları.

Caille, A. (2007), "Sociology as Anti-Utilitarianism”, European Journal of Social Theory, 10(2): 277-86.

Calnitsky, D. (2014), "Economic Sociology as Disequilibrium Economics: A Contribution to the Critique of the New Economic Sociology", The Sociological Review, 62: 565-92.

Corcuff, P. (2009), Bireycilik Sorunu: Stirner, Marx, Durkheim, Proudhon, (Çev. A.U. Kılıç), İstanbul: Versus Kitap.

Denis, H. (1997), Ekonomik Doktrinler Tarihi, (Çev. A. Tokatl1), İstanbul: Sosyal Yayınlar.

Durkheim, E. (1984), The Division of Labour in Society, (Çev. W.D. Halls), London: The Macmillan Press.

Durkheim, E. (2014), Sosyolojik Yöntemin Kuralları, (Çev. Ö. Doğan), Ankara: Doğu Batı Yayınları.

Ercan, F. (1995), “Max Weber'de Yöntem ve Tarihsel İdeal Tip Olarak Kapitalizm

Kavramsallaştırmasının Kapitalist Olmayan Toplumların Gelişme Süreçlerini Anlama Çabaları Üzerindeki Etkileri”, Öneri, 1(3): 127-48.

Fine, B. \& D. Milonakis (2014), İktisat Emperyalizminden Acayip İktisada, (Çev. E. Kırmızıaltın, H. Bilir), Ankara: Heretik.

Freeman, N.C. \& F. Louça (2013), Zaman Akıp Giderken: Sanayi Devrimlerinden Bilgi Devrimine, (Çev. O.S. Binatlı), İstanbul: İthaki Yayınları.

Granovetter, M. (1985), "Economic Action and Social Structure: The Problem of Embeddedness", The American Journal of Sociology, 91 (3): 481-510.

Granovetter, M. (1992), "Economic Institutions as Social Constructions: A Framework for Analysis", Acta Sociologica, 35(1): 3-11.

Granovetter, M. (1990), “The Old and New Economic Sociology: A History and an Agenda”, R. Friedland \& A.F. Robertson (Eds.), Beyond The Market Place: Rethinking Economy and Society, New York, Walter de Gruyter, Inc.

Gülbenkian Komisyonu (2004), Gülbenkian Komisyonu Sosyal Bilimlerin Yeniden Yapılanması Üzerine Rapor, (Çev. Ş. Tekeli), İstanbul: Metis Yayıncılık.

Kabaş, T. (2013), “İktisat Sosyolojisinin Doğuşu ve Yükselişi”, Ç.Ü. Sosyal Bilimler Enstitüsü Dergisi, 22(1): 13-24. 
Kalleberg, A.L. (1995). "Sociology and Economics: Crossing the Boundaries", Social Forces, 73(4): $1207-1218$.

Keat, R. \& J. Urry (2001), Bilim Olarak Sosyal Teori, (Çev. N. Çelebi), İstanbul: İmge Kitabevi.

Kurmuş, O. (2009), Bir Bilim Olarak İktisat Tarihinin Doğuşu, İstanbul: Yordam Kitap.

Ollman, B. (2012), Yabancılaşma Marx’ın Kapitalist Toplumdaki İnsan Anlayışı, İstanbul: Yordam Kitap.

Özatalay, C. (2011), “Türkiye'de "Geri Dönemeyen” Ekonomi Sosyolojisi ya da "Açılamayan” Sosyal Bilimler", Sosyoloji Dergisi, 3(23): 165-82.

Ricardo, D. (1997), Ekonomi Politiğin ve Vergilendirmenin İlkeleri, (Çev. T. Ertan), İstanbul: Belge Yayıncilik.

Smelser, N.J. \& R. Swedberg (2005), "Introducing Economic Sociology”, içinde: N.J. Smelser \& R. Swedberg (Eds), The Handbook of Economic Sociology, USA: Russell Sage Foundation.

Swedberg, R. (1991), "Major Traditions of Economic Sociology", Annual Review of Sociology, 17: 251-76.

Swedberg, R. \& M. Granovetter (1992), “Introduction”, içinde: M. Granovetter \& R. Swedberg (Eds.), The Sociology of Economic Life, USA: Westview Press, Boulder.

Swedberg, R. (1997), "New Economic Sociology: What Has Been Accomplished, What Is Ahead?", Acta Sociologica, 40, 161-82.

Timur, T. (2013), “Marksizmin Klasiklerini Okumak...”, içinde: Marksist Klasikleri Okuma Klavuzu, İstanbul: Yordam Kitap.

Weber, M. (2012), Sosyal Bilimlerin Metodolojisi, İstanbul: Küre Yayınları.

Weber, M. (2013), Protestan Ahlakı ve Kapitalizmin Ruhu, (Çev. M. Köktürk), Ankara: BilgeSu Yayınc1lik.

Yılmaz, F. (2002-3), “İktisat ve Sosyoloji: Rakip Kardeşlerin Hakimiyet Kavgası”, Toplum ve Bilim, 95: 61-84.

Y1lmaz, F. (2012), “İktisat, Kurumsal İktisat ve İktisat Sosyolojisi”, Sosyoloji Konferanslarl, 45: 117. 